\title{
Soil: the great connector of our lives now and beyond COVID-19
}

\author{
Rosa M. Poch ${ }^{1}$, Lucia H. C. dos Anjos ${ }^{2}$, Rafla Attia ${ }^{3}$, Megan Balks ${ }^{4}$, Adalberto Benavides-Mendoza ${ }^{5}$, \\ Martha M. Bolaños-Benavides ${ }^{6}$, Costanza Calzolari ${ }^{7}$, Lydia M. Chabala ${ }^{8}$, Peter C. de Ruiter ${ }^{9,10}$, \\ Samuel Francke-Campaña ${ }^{11}$, Fernando García Préchac ${ }^{12}$, Ellen R. Graber ${ }^{13}$, Siosiua Halavatau ${ }^{14}$, \\ Kutaiba M. Hassan ${ }^{15}$, Edmond Hien ${ }^{16}, \operatorname{Ke~Jin~}^{17}$, Mohammad Khan ${ }^{18}$, Maria Konyushkova $^{19}$, \\ David A. Lobb ${ }^{20}$, Matshwene E. Moshia ${ }^{21}$, Jun Murase ${ }^{22}$, Generose Nziguheba ${ }^{23}$, Ashok K. Patra ${ }^{24}$, \\ Gary Pierzynski $^{25}$, Natalia Rodríguez Eugenio ${ }^{26}$, and Ronald Vargas Rojas ${ }^{26}$ \\ ${ }^{1}$ Department of Environment and Soil Science, Universitat de Lleida, 25198 Lleida, Spain \\ ${ }^{2}$ Department of Soils, Federal Rural University of Rio de Janeiro, CEP 23.897-000, Seropédica, Brazil \\ ${ }^{3}$ Direction Générale de l'Aménagement et de Conservation des Terres Agricoles, Ministère de l'Agriculture, \\ des Ressources Hydrauliques et de la Pêche, 1002 Tunis, Tunisia \\ ${ }^{4}$ School of Science, University of Waikato, Hamilton 3216, New Zealand \\ ${ }^{5}$ Department of Horticulture, Universidad Autónoma Agraria Antonio Narro, Saltillo 25315, Mexico \\ ${ }^{6}$ Colombian Agricultural Research Corporation - AGROSAVIA, Centro de Investigación Tibaitata, \\ Mosquera, Colombia \\ ${ }^{7} \mathrm{CNR}$ - Institute of BioEconomy, 50029 Sesto Fiorentino, Italy \\ ${ }^{8}$ Department of Soil Science, University of Zambia, P.O. Box 32379, Lusaka, Zambia \\ ${ }^{9}$ Biometris, Wageningen University, 6708 PB Wageningen, the Netherlands \\ ${ }^{10}$ Institute for Biodiversity and Ecosystem Dynamics, University of Amsterdam, \\ 1098 XH Amsterdam, the Netherlands \\ ${ }^{11}$ National Forest Corporation, Ministry of Agriculture, Santiago, Chile \\ ${ }^{12}$ Soil and Water Management and Conservation, Facultad de Agronomía, Universidad de la República, \\ Montevideo 12900, Uruguay \\ ${ }^{13}$ The Volcani Center, ARO, Rishon LeZion 7505101, Israel \\ ${ }^{14}$ Ministry of Agriculture, Forestry, Food \& Fisheries, Nuku'alofa, Tonga \\ ${ }^{15}$ Ministry of Agriculture, Baghdad, Iraq \\ ${ }^{16}$ Joseph Ki-Zerbo University, Ouagadougou, Burkina Faso \\ ${ }^{17}$ Grassland Research Institute, Chinese Academy of Agricultural Sciences, \\ Hohhot 010020, Inner Mongolia, China \\ ${ }^{18}$ Department of Soil and Environmental Sciences, The University of Agriculture, Peshawar, Pakistan \\ ${ }^{19}$ Eurasian Center for Food Security, Lomonosov Moscow State University Moscow, Russia \\ ${ }^{20}$ Department of Soil Science, University of Manitoba, Winnipeg, Manitoba R3T 2N2, Canada \\ ${ }^{21}$ Faculty of Science and Agriculture, University of Fort Hare, Alice 5700, South Africa \\ ${ }^{22}$ Graduate School of Bioagricultural Sciences, Nagoya University, Nagoya 464-8601, Japan \\ ${ }^{23}$ International Institute of Tropical Agriculture, Central Africa Hub Coordination Office, Nairobi, Kenya \\ ${ }^{24}$ ICAR-Indian Institute of Soil Science, Bhopal, Madhya Pradesh 462038, India \\ ${ }^{25}$ College of Food, Agricultural, and Environmental Sciences, The Ohio State University, \\ Columbus, OH 43210, USA \\ ${ }^{26}$ Global Soil Partnership, Food and Agriculture Organization of the United Nations, 00153 Rome, Italy
}

Correspondence: Rosa M. Poch (rosa.poch@udl.cat)

Received: 14 June 2020 - Discussion started: 14 July 2020

Revised: 27 August 2020 - Accepted: 23 September 2020 - Published: 5 November 2020 


\begin{abstract}
Humanity depends on the existence of healthy soils, both for the production of food and for ensuring a healthy, biodiverse environment, among other functions. COVID-19 is threatening food availability in many places of the world due to the disruption of food chains, lack of workforce, closed borders and national lockdowns. As a consequence, more emphasis is being placed on local food production, which may lead to more intensive cultivation of vulnerable areas and to soil degradation. In order to increase the resilience of populations facing this pandemic and future global crises, transitioning to a paradigm that relies more heavily on local food production on soils that are carefully tended and protected through sustainable management is necessary. To reach this goal, the Intergovernmental Technical Panel on Soils (ITPS) of the Food and Agriculture Organization of the United Nations (FAO) recommends five active strategies: improved access to land, sound land use planning, sustainable soil management, enhanced research, and investments in education and extension.
\end{abstract}

The soil is the great connector of lives, the source and destination of all. It is the healer and restorer and resurrector, by which disease passes into health, age into youth, death into life. Without proper care for it we can have no community, because without proper care for it we can have no life.

- Wendell Berry (American novelist)

\section{There is no food production without soil}

The coronavirus disease 2019 (COVID-19) pandemic is testing the ability of societies to survive an extreme global situation. Throughout history, humanity has gone through many cataclysms and disasters, but this is the first time in the Anthropocene that we have faced a crisis spanning the whole planet, drastically affecting everybody's lives. The global nature of the pandemic sheds new light on how to ensure food security, which will increasingly depend on sufficient areas of fertile agricultural soils close to population centres. Healthy soils form our most necessary natural resource for food production, on which human existence is dependent (Vargas Rojas et al., 2016).

It is obvious that the COVID-19 pandemic will significantly reshape our lives well into the future, not just during this acute phase. In this vision paper, we, members of the Intergovernmental Technical Panel on Soils $\left(\right.$ ITPS $\left.^{1}\right)$ of the $\mathrm{FAO}^{2}$, share our understanding of the crucial role played by sustainable soil management in the new global reality. Indeed, appropriate soil management is imperative for solving and anticipating food security and nutrition requirements that governments and individuals will face in the post-pandemic world.

Our global society often relies on dense and interconnected networks of socio-economic relationships, which, in many respects, are far from efficient from an environmental point of view and do not always support people's food and nutritional needs. Our health is directly linked to the qual-

\footnotetext{
${ }^{1}$ The ITPS is composed of 27 well-recognized soil scientists from all over the world (http://www.fao.org/global-soil-partnership/ intergovernmental-technical-panel-soils/en/, last access: 30 October 2020).

${ }^{2}$ Food and Agriculture Organization of the United Nations (http: //www.fao.org/home/en/, last access: 30 October 2020)
}

ity of the environment in which we live and to the food we eat, as addressed by the "One Health Initiative"3. The decline of environmental quality, caused by urban development and intensive agriculture, has led in many places to significant losses of natural habitats and biodiversity (FAO et al., 2020). Human impacts on the environment exacerbate the appearance and spread of pathogens (FAO et al., 2020). Strong policies and actions that support healthy and productive soils are needed to assure global food security and sovereignty for urban and rural populations around the world (Wittman and Blesh, 2017). It is vital that soils within or near cities are available, unpolluted, and managed sustainably, to ensure that they can contribute to safe local food production systems.

\section{Impact of COVID-19 pandemic on food and soil security}

It has been predicted that more people will die from hunger and starvation due to disrupted food production chains during the pandemic than from the disease itself (FSIN, 2020). Lack of workforce for harvesting and processing, restrictions in transportation and movement of workers due to closed borders and national lockdowns, and shortages of production materials (e.g. seeds, fertilizers) have the potential, in some regions, to cause severe shortcomings in food availability. Even in areas where crop production is not disrupted, many cropping systems are monocultures designed for export and cannot provide a well-rounded diet for local and national populations. Moreover, the disproportionate loss of

\footnotetext{
${ }^{3}$ The One Health Initiative is a worldwide strategy for expanding interdisciplinary collaborations and communications in all aspects of health care for humans, animals and the environment (http: //www.onehealthinitiative.com/, last access: 30 October 2020)
} 
older people due to the COVID-19 is a threat to secure food production because, in many parts of the world, the vast majority of farmers and people with experience in agricultural management and understanding soil are over 50 years of age (e.g. IFAD, 2019; Eurostat, 2018). Thus, the pandemic may result in a considerable dearth of expertise in the future (Huynh et al., 2020) and thus reduced ability to continue to produce food and manage the soil sustainably everywhere around the globe.

The food supply in urban environments relies on longer and more complex food chains than in rural ones. The main effect of the pandemic in urban environments has been the excessive increase of food prices and food shortages, mainly in low-income countries (Mukiibi, 2020; Competition Commission, 2020). In this situation, urban agriculture, which is already producing about $15 \%-20 \%$ of the world's food supply (Lal, 2020b) is playing a critical role in cities with acute food shortages due to the COVID-19. Higher-income urban environments are less affected and have undergone changes in food habits, such as the increase of online food demand (Chang and Meyerhoefer, 2020). In rural areas of low-income countries, farmers are experiencing more severe problems, such as difficulties in purchasing seeds and fertilizers and getting produce to markets (World Farmers Organisation, 2020), besides the financial barriers to credit access. Some cases of illegal land clearing by companies while the locals were locked down have also been reported (Fox et al., 2020).

Additionally, the pressures of the COVID-19 crisis on food systems will also have a direct impact on soil security (Koch et al., 2013). International transport limitations will require a greater emphasis on local and national food production. In places where land suitable for agricultural use is limited, more intensive cultivation of already degraded soils and expansion of agriculture to vulnerable areas could lead to increased soil degradation if not well managed (Willi et al., 2019). Degradation results from depletion of soil carbon and nutrients, increased erosion, over-fertilization, soil salinization, soil pollution and, eventually, the loss of soils (Stocking, 2003), which are non-renewable resources. Soil degradation also results in increased atmospheric $\mathrm{CO}_{2}$ emissions, which contribute to climate change (Olsson et al., 2019).

Perhaps the two main threats in the short term are soil pollution and nutrient depletion. Increase of urban agriculture is faced with the fact that contamination by heavy metals, organic pollutants, antibiotics and petroleum products are among the major constraints limiting the use of urban soils for food production (Menefee and Hettiarachichi, 2018). Moreover, there is evidence that the enormous quantity of disposable plastic gloves and face masks that get into the environment (soils and waters) could increase the accumulation of their related microplastics and fibres within a short time (Fadare and Okoffo, 2020; Aragaw, 2020). Another effect derives from the lack of access to fertilizers to small farmers in low-income countries, as has already been reported in Thai-

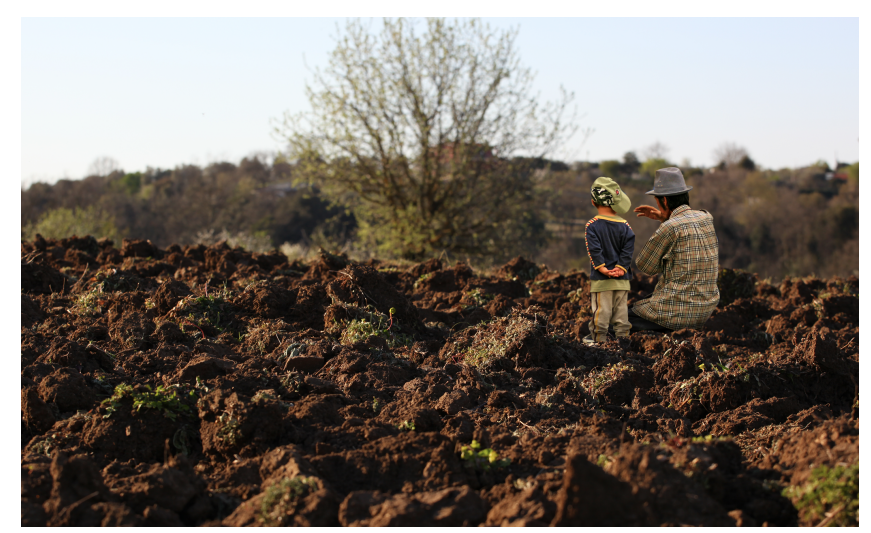

Figure 1. In the heart of the sustainability concept, the connection with the land and respectfulness between generations lies in the basics and secrets about how to care for soil, which are transferred from older generations to the youth. (C) Matteo Sala.

land (Fox et al., 2020), which can easily lead to degradation by nutrient depletion.

\section{Sustainable soil management to create and strengthen food systems}

To prepare for a global disruption of food production from whatever cause, we suggest a general transition from the current emphasis on globalized food chains (King et al., 2017) to a more balanced approach that also includes well-rounded and diverse local, national and regional food chains. Such a transition will help to build more resilient and secure societies and is in the best interest of countries concerned about the welfare of their citizens. Countries and regions will need to identify ways to promote local food production, a circular agro-economy and recycling residues with potential for agricultural use (Jurgilevich et al., 2016).

Together with such a transition, soils must be carefully tended and protected (Fig. 1). It is essential that we invest in the sustainability of food production systems, and this implies caring for long-term soil health so as to preserve soil structure, fertility, balanced organic matter and nutrients dynamics, biodiversity, and all the related soil ecosystem services (Lal, 2020a). Sustainable food production systems, in particular those that ensure food security for local populations, will require a transformation from land used for extensive large-scale monocultures to highly diverse local agriculture, especially when they are near or within cities, in order to promote food-resilient urban centres (Fig. 2). This change must go hand in hand with the strengthening of small farmers' capacities and soil awareness. It will also be increasingly important to ensure that populations do not exceed the carrying capacity of the lands on which they depend.

Several initiatives, since the onset of the pandemic and the beginning of food supply problems, have appeared around the world demonstrating that it is possible to improve food 


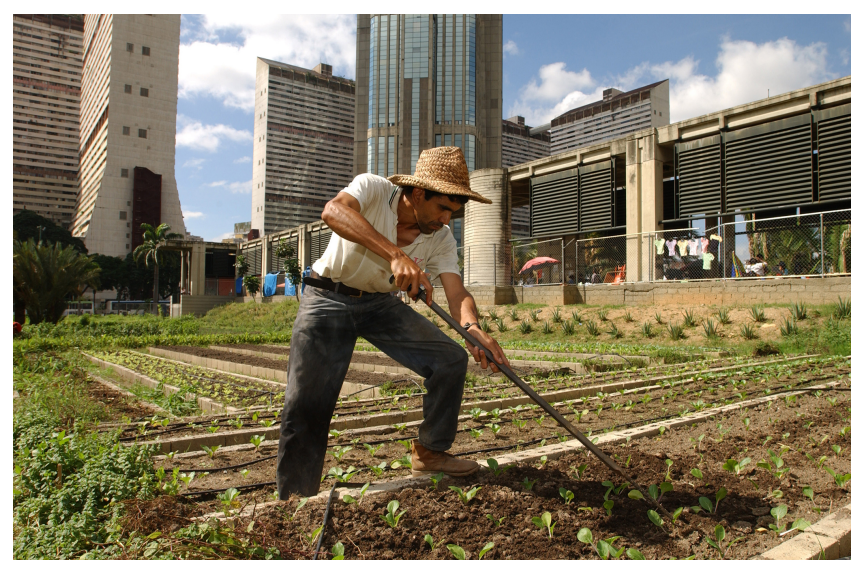

Figure 2. Urban and peri-urban agriculture to improve nutrition and livelihoods of poor families as part of the Special Programme for Food Security (SPFS) in Caracas, Venezuela. (C) FAO/Giuseppe Bizzarri.

sovereignty thanks to the collaborative work of people. For instance, communities from Sabah (Malaysian Borneo), who are dependent on imports for $75 \%$ of their rice requirements and are having problems sourcing rice from Vietnam and selling cash crops, have recovered their traditional practices and river culture to maintain their protein supply (Ong and Wilson, 2020). In Emilia-Romagna (Italy), a region severely affected by the pandemic, farmer self-organization has ensured the provision of local food, making shorter chains (Diesner, 2020). Other initiatives, such as Slow Food Gardens in many countries in Africa, are strengthening rural small-scale producer communities and therefore ensuring food supply (Mukiibi, 2020). Rural communities in the developing world will require affordable and locally adapted technologies to maintain soil health while supporting diverse and well-rounded food production. For the long term, this requires governments and land owners to care about soils as a finite resource and to implement measures to prevent their degradation (FAO, 2017; Batini et al., 2020).

Future agricultural policies should focus on coherent global agricultural regulations to avoid counterproductive market interferences and to promote collaboration, and they should direct the transition to more diverse balanced systems. In this way, food security can be achieved as much as possible on the basis of local food production chains. Governments should also support research and educational areas that focus on food security (soil, water, seeding, management systems, processing, etc.) even in the midst of global health challenges, since they will be even more important to building post-COVID-19 food resilience. Many countries have strategic grain reserves for meeting future national or international needs that can solve acute food shortages. In much the same way, we need to create "strategic soil reserves". By this, we do not mean locking away soils that can then be released in the event of a future catastrophic loss of soil. We mean preserving, improving, rehabilitating and protecting lands suitable for agriculture, especially our best periurban soils from urban development. Strategic soil reserves can help solve long-term chronic food shortages.

Soil security, as part of global, regional, national and local strategies, will ensure resilience in the face of such crises as we are now experiencing. The overarching goal should be to achieve global food security and avoid enlarging gaps between societies. The above is in line with the UN Sustainable Development Goals: no poverty, zero hunger, clean water, sustainable cities, responsible consumption and production, climate action, and life on land. The Global Soil Partnership recommendations as presented in the Voluntary Guidelines for Sustainable Soil Management (FAO, 2017) or the proposed RECSOIL (FAO, 2019a) mechanism to increase the resilience of soils by increasing soil organic carbon, in the frame of the Koronivia Joint Work on Agriculture Roadmap (FAO, 2018), are now more relevant than ever.

The COVID-19 crisis has focused the world's attention on the vulnerability of its food systems and the need to sustain food production at a regional/country level. In view of the foregoing, the ITPS recommends five active strategies that will ensure that each region/country has enough productive soil that can be managed sustainably to feed its population. These strategies are access to land, sound land use planning, sustainable soil management, research, and education and extension.

- Access to land. It is necessary to revisit the national policies on land tenure to regulate international land ownership. The access of local people to land, food and livelihood must be ensured by avoiding infringement of tenure rights by business enterprises or states (FAO, 2012). In the same way, it is also critical to revisit the importance of small family farms, which contribute greatly to maintenance of healthy soils and resilience of local communities in case of crisis.

- Sound land use planning. The need to preserve and improve local lands with agricultural potential and also to convert or rehabilitate marginal areas when food production is needed, while protecting vital ecosystems, must become a part of land use planning in all urban and rural development schemes. In particular, those soils that have a high value for food production should be protected from land sealing due to urbanization, infrastructure or industrial activities. This can be done, for example, by producing soil suitability maps for crops, using approaches such as the agro-ecological zone (AEZ) (FAO, 2002).

- Sustainable soil management. Site-specific conservation agriculture measures are needed to prevent land degradation and desertification. This will ensure the availability of productive soils for present and future generations. In particular, this requires taking appro- 
priate actions to maintain and, where needed, improve soil fertility through integrated fertilization. Fertilization regimes should consider the nutritional requirements of the crops, the interactions of nutrients with the different soils and their intrinsic fertility, and the development of strategies that minimize soil pollution (FAO, 2019b). In particular, the development of food production in urban areas needs to be approached with caution and to include suitable testing, to ensure that existing soil pollution does not lead to toxic levels of contaminants in the produced food ( $\mathrm{Li}$ et al., 2018).

- Research. Sustainable and resilient soil systems for food production will require increasing research efforts with new approaches and interdisciplinarity. The threats to sustainable soil management are not new, but research dealing with preserving soil quality for agriculture and reversal of soil degradation will be even more important. Much more research is needed on how to increase and maintain soil organic carbon (Torquebiau et al., 2018). Research in land sealing should be revisited to learn how to "de-seal" soils to bring them back into sustainable use for agriculture and forestry (Artmann, 2016). The focus on urban and peri-urban soils for food production must not be overlooked .

- Education and extension. The inclusion of soils in all levels of education curricula is necessary to increase awareness on the importance of soils in our lives. The strengthening of extension services, technology transfer and capacity-building programmes will support local farmers in applying sustainable practices. The development of mobile soil labs would help with fast diagnoses and with solving problems locally.

From its inception in 2012, the Global Soil Partnership of FAO is working in all these aspects through its five pillars of action (soil management, awareness raising, promoting research, information and data, harmonization), which will acquire more importance in the light of global crises.

Soils are a finite, non-renewable, multi-systemic source of life, and still they are easily overlooked in decision-making acts and policies. A new post-pandemic reality should ensure that soil is recognized as the great connector and service provider that links our lives to all human needs of food, health and security (Moyer, 2020). Caring for soils is imperative to reduce the impacts of global disturbances, such as the current COVID-19 crisis.

Data availability. No data sets were used in this article.

Author contributions. The authors have contributed in the following ways:

RMP: conceptualization, writing - original draft preparation, review and editing, visualization; LHCDA: writing - original draft preparation, review and editing; RA: writing - original draft preparation, review and editing; $\mathrm{MB}$ : writing - original draft preparation, review and editing; $A B M$ : writing - original draft preparation, review and editing; MMBB: writing - original draft preparation, review and editing; $\mathrm{CC}$ : writing - original draft preparation, review and editing; LMC: writing - original draft preparation, review and editing; PCDR: writing - original draft preparation, review and editing; SFC: writing - original draft preparation, review and editing; FGP: writing - original draft preparation, review and editing, erg: writing - original draft preparation, review and editing; $\mathrm{SH}$ : writing - original draft preparation, review and editing, $\mathrm{KMH}$ : writing - original draft preparation, review and editing; EH: writing - original draft preparation, review and editing; KJ: writing - original draft preparation, review and editing; MK: writing - original draft preparation, review and editing; MK: writing - original draft preparation, review and editing; DAL: writing - original draft preparation, review and editing; MEM: writing - original draft preparation, review and editing; JM: writing - original draft preparation, review and editing; GN: writing - original draft preparation, review and editing; AKP: writing - original draft preparation, review and editing; GP: writing - original draft preparation, review and editing; NRE: writing - original draft preparation, review and editing, visualization; RVR: writing - original draft preparation, review and editing.

Competing interests. The authors declare that they have no conflict of interest.

Acknowledgements. This article is an initiative of the ITPS. As such it has been elaborated on, reviewed by and endorsed by its members, in close collaboration with the GSP Secretariat.

Review statement. This paper was edited by John Quinton and reviewed by three anonymous referees.

\section{References}

Aragaw, T. A.: Surgical face masks as a potential source for microplastic pollution in the COVID-19 scenario, Mar. Pollut. Bull., 111517, https://doi.org/10.1016/j.marpolbul.2020.111517, 2020.

Artmann, M.: Urban gray vs. urban green vs. soil protection - Development of a systemic solution to soil sealing management on the example of Germany, Environ. Impact Asses., 59, 27-42, https://doi.org/10.1016/j.eiar.2016.03.004, 2016.

Batini, N., Lomax, J., and Mehra, D.: Why sustainable food systems are needed in a post-COVID world. World Economic Forum, available at: https://www.weforum.org/agenda/2020/ 07/sustainable-food-systems-covid19-coronavirus/, last access: 30 October 2020.

Chang, H. H. and Meyerhoefer, C.: COVID-19 and the Demand for Online Food Shopping Services: Empirical Evidence from Taiwan (No. w27427), National Bureau of Economic Research, available at: https://doi.org/10.3386/w27427, last access: 30 October 2020 . 
Competition Commission South Africa: Joint briefing to the portfolio committee on trade and industry and select committee on economic development, Small Business Development, Tourism, Employment and Labour: 19 May 2020, available at: http://www.thedtic.gov.za/wp-content/uploads/ Competition-Commission19-May-2020.pdf, last access: 29 July 2020.

Diesner, D.: Self-governance food system before and during the Covid-crisis on the example of CampiAperti, Bologna, Italy, Interface: a journal for and about social movements, 12, 266-273, 2020.

Eurostat: Farming: profession with relatively few young farmers, available at: https://ec.europa.eu/eurostat/web/ products-eurostat-news/-/DDN-20180719-1 ?inheritRedirect= true (last access: 30 October 2020), 2018.

Fadare, O. O. and Okoffo, E. D.: Covid-19 face masks: A potential source of microplastic fibers in the environment, Sci. Total Environ., 737, 140279, https://doi.org/10.1016/j.scitotenv.2020.140279, 2020.

FAO: GAEZ: Global Agro-Ecological Zones, Food and Agriculture Organization of the United Nations, available at: http://www.fao. org/nr/gaez/en/, last access: 24 April 2002.

FAO: Voluntary guidelines on the responsible governance of tenure of land, fisheries and forests in the context of national food security, Food and Agriculture Organization of the United Nations, Rome, 2012.

FAO: Voluntary Guidelines for Sustainable Soil Management, available at: http://www.fao.org/3/i6874en/I6874EN.pdf (last access: 16 January 2019), 2017.

FAO: The Koronivia Joint Work on Agriculture Road Map, Food and Agriculture Organization of the United Nations, available at: http://www.fao.org/climate-change/our-work/ what-we-do/koronivia/kjwa-road-map/en/ (last access: 24 April 2020), 2018.

FAO: RECSOIL: recarbonization of global soils to offset global emissions, Global Soil Partnership, available at: http://www.fao.org/global-soil-partnership/resources/highlights/ detail/en/c/1201385/ (last access: 24 April 2020), 2019a.

FAO: The International Code of Conduct for the Sustainable Use and Management of Fertilizers, available at: http://www.fao.org/ 3/mz476en/mz476en.pdf (last access: 30 October 2020), 2019b.

FAO: FAO, CBD and GSBI: State of knowledge of soil biodiversity. Status, challenges and potentialities, Food and Agriculture Organization of the United Nations, Rome, Italy, 2020.

Fox, J. M., Promkhambut, A., and Yokying, P.: Impact of COVID19 on rice farmers in Southeast Asia, East-West Wire, 3-July 2020, available at: https://www.eastwestcenter.org/news-center/ east-west-wire/impact-covid-19-rice-farmers-in-southeast-asia, last access: 29 July 2020.

FSIN: Global Report on Food Crises. Joint analysis for better decisions, World Food Programme, 2020.

Huynh, H. T., de Bruyn, L. A. L., Wilson, B. R., and Knox, O. G.: Insights, implications and challenges of studying local soil knowledge for sustainable land use: a critical review, Soil Res., 58, 219-237, https://doi.org/10.1071/SR19227, 2020.

International Fund for Agricultural Development (IFAD): Rural Development Report 2019, available at: https://www.ifad.org/en/ web/knowledge/publication/asset/41173272 (last access: 30 October 2020), 2019.
Jurgilevich, A., Birge, T., Kentala-Lehtonen, J., Korhonen-Kurki, K., Pietikäinen, J., Saikku, L., and Schösler, H.: Transition towards circular economy in the food system, Sustainability-Basel, 8, 1-14, https://doi.org/10.3390/su8010069, 2016.

King, T., Cole, M., Farber, J. M., Eisenbrand, G., Zabaras, D., Fox, E. M., and Hill, J. P.: Food safety for food security: Relationship between global megatrends and developments in food safety, Trends Food Sci. Tech., 68, 160-175, https://doi.org/10.1016/j.tifs.2017.08.014, 2017.

Koch, A., Mcbratney, A., Adams, M., Field, D., Hill, R., Crawford, J., Minasny, B., Lal, R., Abbott, L., O’Donnell, A. G., Angers, D., Baldock, J., Barbier, E., Binkley, D., Parton, W., Wall, D. H., Bird, M., Bouma, J., Chenu, C., Flora, C. B., Goulding, K., Grunwald, S., Hempel, J., Jastrow, J., Lehmann, J., Lorenz, K., Morgan, C. L., Rice, C. W., Whitehead, D., Young, I., and Zimmermann, M.: Soil Security: Solving the Global Soil Crisis, Glob. Policy, 4, 434-441, https://https://doi.org/10.1111/17585899.12096, 2013.

Lal, R.: Soil science beyond COVID-19, J. Soil Water Conserv., 75, 79A-81A, https://https://doi.org/10.2489/jswc.2020.0408A, 2020a.

Lal, R.: Home gardening and urban agriculture for advancing food and nutritional security in response to the COVID-19 pandemic, Food Sec., 12, 871-876, https://doi.org/10.1007/s12571020-01058-3, 2020b.

Li, G., Sun, G. X., Ren, Y., Luo, X. S., and Zhu, Y. G.: Urban soil and human health: a review, Eur. J. Soil Sci., 69, 196-215, https://doi.org/10.1111/ejss.12518, 2018.

Menefee, D. S. and Hettiarachichi, G. M.: Contaminants in urban soils: Biodiversity and transfer, in: Urban Soils, edited by: Lal, R. and Stewart, B. A., Boca Raton, CRC Press, 175-187, 2018.

Moyer, J.: A time of reflection: a time for change, Agric. Hum. Values, 1, 37, 581-582, https://doi.org/10.1007/s10460-020-10075z, 2020.

Mukiibi, E.: COVID-19 and the state of food security in Africa, Agric. Hum. Values, 37, 627-628, https://doi.org/10.1007/s10460-020-10079-9, 2020.

Olsson, L., Barbosa, H., Bhadwal, S., Cowie, A., Delusca, K., Flores-Renteria, D., Hermans, K., Jobbagy, E., Kurz, W., Li, D., Sonwa, D. J., and Stringer, L.: 2019: Land Degradation, in: Climate Change and Land: an IPCC special report on climate change, desertification, land degradation, sustainable land management, food security, and greenhouse gas fluxes in terrestrial ecosystems, edited by: Shukla, P. R., Skea, J., Calvo Buendia, E., Masson-Delmotte, V., Pörtner, H.-O., Roberts, D. C., Zhai, P., Slade, R., Connors, S., van Diemen, R., Ferrat, M., Haughey, E., Luz, S., Neogi, S., Pathak, M., Petzold, J., Portugal Pereira, J., Vyas, P., Huntley, E., Kissick, K., Belkacemi, M., and Malley, J., Intergovernmental Panel on Climate Change, available at: https://www.ipcc.ch/srccl/chapter/chapter-4/ (last access: 30 October 2020), 2019.

Ong, C. and Wilson, K.: Rice revitalization and food sovereignty in Sabah, Agric. Hum. Values, 37, 555-556, https://doi.org/10.1007/s10460-020-10082-0, 2020.

Stocking, M. A.: Tropical soils and food security: the next 50 years, Science, 302, 1356-1359, https://doi.org/10.1126/science.1088579, 2003.

Torquebiau, E., Rosenzweig, C., Chatrchyan, A. M., Andrieu, N., and Khosla, R.: Identifying Climate-smart 
agriculture research needs, Cah. Agric., 27, 26001, https://doi.org/10.1051/cagri/2018010, 2018.

Vargas Rojas, R., Achouri, M., Maroulis, J., and Caon, L.: Healthy soils: a prerequisite for sustainable food security, Environ. Earth Sci., 75, 1-10, https://doi.org/10.1007/s12665-015-50997, 2016.

Willy, D. K., Muyanga, M., and Jayne, T.: Can economic and environmental benefits associated with agricultural intensification be sustained at high population densities? A farm level empirical analysis, Land Use Policy, 81, 100-110, https://doi.org/10.1016/j.landusepol.2018.10.046, 2019.
Wittman, H. and Blesh, J.: Food Sovereignty and Fome Zero: Connecting Public Food Procurement Programmes to Sustainable Rural Development in Brazil, J. Agrar Change, 17, 81-105, https://doi.org/10.1111/joac.12131, 2017.

World Farmers Organisation: Covid-19 pandemic outbreak: overview of the impact on the agricultural sector, available at: https://www.wfo-oma.org/wp-content/uploads/2020/05/ COVID19-WFO-technical-assessment_005082020.pdf, last access: 30 October 2020 . 